\title{
ELECTROENCEPHALOGRAPHIC AND ELECTROCARDIOGRAPHIC. PATTERNS DURING OPEN HEART OPERATIONS WITH THE USE OF CARDIOPULMONARY BYPASS ${ }^{1,2}$
}

\author{
Eva M Kavan, m D, Verne L Brechner, M D., Richard D. Walter, M D, \\ and LEONARD M LINDE, $\mathrm{M} \mathrm{D}^{3}$
}

SINCE THE EARLY PART OF 1956, various congenital cardiac anomalies have been operated upon at the University of California Medical Center, Los Angeles, using cardiopulmonary bypass. This report discusses certain observations made on 25 patients who underwent cardiac surgery during 1957, with the and of the Gibbon screen oxygenator. The bypass apparatus, as modified by our surgical team, has been described in another publication (7). During the entire period of anaesthesia, contınuous electrocardıographic and electroencephalographic tracings were recorded, while effects of the anaesthetic agent and other variables were carefully noted. Preoperative diagnosis of the majority of patients (18 total) was interventricular septal defect Other diagnoses were: transposition of the great vessels in two patients and one case of each of the following. bicuspid aortic valve, pulmonary valve and infundibular stenosis, atrial septal defect with anomalous pulmonary veins, atrioventricular communis with other anomalies, and rheumatic mitral stenosis and insufficiency (Table I) Except for the patients with atrial septal defect, operation was performed in all instances as a life-saving measure because of progressive deterioration of the patient

\section{METHOD}

The physical status of each patient was evaluated by the cardiologist and by the anaesthetist All 25 patients were considered as severe or extremely severe operative risks (Physical Status (P.S ) no. 3 and no 4) P S no. 3 included children who were relatively well developed and who had not been cyanotic or recently in cardiac failure In this group were eight of the 18 patients with interventricular septal defect. PS. no 4 was the classification given to patients who were cyanotic and poorly developed, or who were receiving digitalis therapy at the time of operation (Table II). Five patients in this category were under one year of age, the youngest being 11 days old Seventeen patients were from one to eight years of age, while three patients were young aclults. Angiocardiographic studies, cardiac catheterization data, functional status of the heart, and age were all taken into consideration in evaluating each patient as a surgical risk.

1This work was supported by grant-1n-and no H-2812, United States Public Health Service, National Institutes of Health, Bethesda, Maryland.

2Read before the Annual Meeting of the Canadian Society of Anaesthetists in Montebello, Quebec, Canada, June 24, 1958.

3From the Departments of Surgery (Anesthesia), Medicine (Neurology), and Pediatrics, University of Californıa Medical Center, Los Angeles, Calif. 
TABLE I

Diagnoses and Pertinejut Diagnostic Data of 25 Cases of Open Heart Surgery

\begin{tabular}{|c|c|c|c|c|c|c|}
\hline \multicolumn{2}{|c|}{$(\mathrm{yrs}) \stackrel{\text { Age }}{(\mathrm{mos}}$} & \multirow[t]{2}{*}{ Diagnosis } & \multirow{2}{*}{$\begin{array}{c}\begin{array}{c}\text { Systemic } \\
\text { PR }\end{array} \\
\frac{90}{9}\end{array}$} & \multirow{2}{*}{$\begin{array}{r}\text { R V } \\
\text { PR. } \\
62\end{array}$} & \multirow{2}{*}{$\frac{\begin{array}{c}\text { Anaesthetic } \\
\text { agent }\end{array}}{\mathrm{C}^{*}}$} & \multirow{2}{*}{$\frac{\text { Result }}{\mathrm{L}}$} \\
\hline 6 & & & & & & \\
\hline 6 & 6 & VSD, Multıple & 70 & 50 & $\mathrm{C}$ & $\mathrm{L}$ \\
\hline 1 & 3 & VSD & 100 & 38 & $\mathrm{C}$ & $\mathrm{L}$ \\
\hline 4 & & VSD & 85 & 89 & $\mathrm{C}$ & $\mathrm{R}^{*}$ \\
\hline & 2 & Atrioventricular communis, pulmonary valve, & 80 & 83 & $\mathrm{C}$ & $\mathrm{L}$ \\
\hline 2 & 9 & VSD & 90 & 55 & $\mathrm{c}$ & $\mathrm{R}$ \\
\hline & 6 & VSD, multıple & 92 & 55 & C & $T^{*}$ \\
\hline & 11 & VSD, multiple & 90 & 60 & $\mathrm{C}$ & $\mathbf{L}$ \\
\hline 6 & & VSD & 84 & 42 & $\mathrm{C}$ & $\overline{\mathrm{L}}$ \\
\hline 1 & & Bicuspid aortic valve & 80 & 59 & $\mathrm{C}$ & $\mathrm{R}$ \\
\hline 15 & & VSD & 130 & 45 & $C$ and $E^{*}$ & $* \mathrm{~L}$ \\
\hline & 2 & $\begin{array}{l}\text { Transposition, patent ductus arteriosus, } \\
\text { bicuspid aortic and pulmonary valve }\end{array}$ & - & - & $\mathrm{C}$ & $\mathrm{T}$ \\
\hline $2 \mathrm{wks}$ & & Transposition, patent ductus arteriosus & 100 & 100 & $\mathrm{C}$ & $\mathrm{T}$ \\
\hline 3 & 3 & VSD & 112 & 38 & $\mathrm{E}$ & $\mathrm{L}$ \\
\hline 31 & & VSD & 136 & 80 & $\mathrm{E}$ & $\mathrm{L}$ \\
\hline 5 & & VSD & 121 & 98 & $\mathrm{E}$ & $\bar{R}$ \\
\hline 2 & & Pulmonary inf and valve stenosis & 104 & 98 & $\mathrm{E}$ and $\mathrm{C}$ & C $\mathrm{R}$ \\
\hline 23 & & Rheumatic heart disease, mitral stenosis, & $\longrightarrow$ & - & $\mathrm{F}$ & $T$ \\
\hline 3 & & $\begin{array}{l}\text { mitral } 1 \\
\text { VSD }\end{array}$ & $\overrightarrow{100}$ & $\overline{60}$ & $\stackrel{\mathrm{E}}{\mathrm{E}}$ & $\mathrm{T}$ \\
\hline 5 & & Total anomalous pulmonary veins drainage & 96 & 35 & $\mathrm{E}$ & $\mathrm{L}$ \\
\hline 2 & 2 & VSD & 120 & 40 & $\mathrm{E}$ & $\mathrm{R}$ \\
\hline 3 & $\overline{7}$ & VSD & 80 & 76 & $\mathrm{E}$ & $\overline{\mathrm{L}}$ \\
\hline 3 & 3 & VSD & 57 & 34 & $\bar{E}$ & L \\
\hline 2 & 7 & VSD & 100 & 30 & $E$ & $\mathrm{~L}$ \\
\hline 8 & 4 & VSD & 110 & 6.5 & $\mathrm{E}$ & $\mathrm{L}$ \\
\hline
\end{tabular}

*VSD $=$ intraventricular defect, $\mathrm{C}=$ cyclopropane, $\mathrm{E}=$ ether, $\mathrm{R}=$ died in recovery room, $\mathrm{T}=$ died on table

Preoperative medication consisted of meperıdıne, $1 \mathrm{mg} / \mathrm{kg}$. body weight, with appropriate doses of atropine given 90 minutes prior to incision time In critically ill patients, the dose of meperidme was decreased by 25 per cent, while in children less than one year of age none was given.

With two exceptions, all anaesthetics were admmistered by the same person ( $\mathrm{EM} \mathrm{K}$ ).

Two patients received $100 \mathrm{mg}$ of thiopental intravenously for induction, in all others, anaesthesia was induced by cyclopropane. In the first 12 patients, cyclopropane served as the sole agent. In 11 patients, after consciousness was lost, ether was started and contunued as the only anaesthetic agent for the remainder of the procedure. In two instances, both cyclopropane and ether were employed. Closed circuit carbon dioxide absorption technique was used in all instances. On 12 occasions, intravenous or intramuscular succinylcholine was employed to facilitate endotracheal intubation

A venous cut-down for the admunistration of blood and fluids and an arterial cut-down for direct measurement of blood pressure during operation were instituted by the members of the surgical team as soon as an adequate level of general anaesthesia was achieved.

Preoperative electrocardiograms were obtained in all patients, and a continuously monitored record was secured throughout the operative procedure In 
order to ensure a good electrocardiographic tracing during operation and yet avoid the sterile operative field, needle electrodes were placed in each scapular region, thus providing a modified lead I.

Preoperative electroencephalographic tracings were obtained in all instances and the electrical cortical activity was contınuously monitored throughout the administration of anaesthesia. These tracings were obtained by the scalp-toscalp technique, and recorded on seven channels of the clinical Grass electroencephalographic machine, the electrocardıogram was recorded on the eighth channel.

Rectal temperatures of all patients were monitored with a thermister. The actual operation was usually begun 45 minutes to 1 hour after induction of anaesthesia, when all preliminary procedures had been completed. Both anaesthesia and operatıng times are summarized in Table II.

TABLE II

IMPORTANT FaCTORS IN OPEN HEART OPERATIONS

\begin{tabular}{|c|c|c|c|c|c|}
\hline Surgical risk & Cardiac risk & Art & Operating time & Anaesthesta & Pump time (mins) \\
\hline 4 & 4 & $\mathrm{SC}^{*}$ & 410 & 520 & 21 \\
\hline 3 & 2 & $\mathrm{SC}$ & 355 & 505 & 22 \\
\hline 3 & 3 & SC & 430 & 545 & 21 \\
\hline 4 & 4 & $\mathrm{SC}$ & 410 & 520 & 21 \\
\hline 4 & 4 & $\mathrm{SC}$ & 400 & 540 & 22 \\
\hline 4 & $\begin{array}{l}x \\
3\end{array}$ & $\mathrm{~F}^{*}$ & 310 & 5.00 & 23 \\
\hline 4 & 4 & $\mathrm{~F}$ & 410 & 5.30 & 78 \\
\hline 4 & 4 & $\mathrm{~F}$ & 320 & 45 & 22 \\
\hline 4 & 2 & $\mathrm{~F}$ & 340 & 530 & 20 \\
\hline 4 & 4 & $\mathrm{~F}$ & 345 & 525 & 25 \\
\hline 3 & 2 & $\mathrm{~F}$ & 430 & 640 & 15 \\
\hline 4 & 4 & $\mathrm{SC}$ & 448 & 613 & 56 \\
\hline 4 & 4 & $\mathrm{SC}$ & 550 & 725 & 68 \\
\hline 3 & 2 & $\mathrm{SC}$ & 410 & 550 & 42 \\
\hline 4 & 4 & $\mathrm{~F}$ & 450 & 700 & 23 \\
\hline 4 & 4 & $F$ & 520 & 620 & 36 \\
\hline 4 & 4 & $\mathrm{SC}$ & 355 & b 20 & 36 \\
\hline 4 & 4 & $\mathrm{~F}$ & 445 & 540 & 76 \\
\hline 3 & 3 & $\mathrm{~F}$ & 412 & 450 & 20 \\
\hline 3 & 3 & $\mathrm{~F}$ & $\begin{array}{ll}3 & 12\end{array}$ & 510 & 36 \\
\hline 3 & 2 & $\mathrm{~F}$ & 340 & 510 & 23 \\
\hline 4 & 4 & $\mathrm{~F}$ & 350 & 455 & 23 \\
\hline 4 & 2 & $\mathrm{~F}$ & 340 & 445 & 12 \\
\hline 3 & 2 & $\mathrm{~F}$ & 325 & 430 & 19 \\
\hline 4 & 2 & $\mathrm{~F}$ & 345 & 500 & 27 \\
\hline
\end{tabular}

*SC $=$ subclavian, $F=$ femoral

In all cases, anaesthesia was somewhat deepened just prior to the onset of extracorporeal curculation No anaesthetics were administered durıng the actual bypass or immediately after the perfusion perrod. Minimal amounts of the agent used previously were administered for 2 to 3 minutes at a time, and only if the patient moved head or limb during the closure of the chest. In four instances muscle relaxants were administered through the arterial inflow of the pump when diaphragmatic movements seemed to interfere with the surgical procedure

The period of the cardiopulmonary bypass averaged 22 to 25 minutes. The duration of extracorporeal circulation was more prolonged during procedures 
other than closure of interventricular septal defect. In one instance there were technical difficulties with the pump oxygenator. Heparinization of the patient's blood in preparation for peifusion and administration of protamine after the bypass was handled by the surgical team. The desired pump flow rate was 70 $\mathrm{ml} . / \mathrm{kg}$. body weight $/ \mathrm{mm}$. In the first 10 patients, the blood used in the pump oxygenator was kept at room temperature, while in the remaining 15 patients four 250-watt infrared lamps were placed about 8 in. from the oxygenator screen to increase the temperature of the blood to $37^{\circ} \mathrm{C}$. Thus, sudden decrease in body temperature during the period of extracorporeal crrculation was minmized and rarely decreased more than one degree.

\section{Results AND Discussion}

Of the 25 patients operated upon, 11 died. Three infants and one extremely ill adult (with diagnosis of mitral stenosis) died in the operating room. The remaining 7 died within a few hours after completion of the operation.

\section{Electrocardiographic Observations}

By placing the needle electrodes on each scapular region, a tracing similar to lead I of the standard electrocardiogram was obtamed. While the main deflection, such as the $\mathrm{P}, \mathrm{QRS}, \mathrm{T}$ waves, the cardiac rate, and the general electrocardıographic configuration, could be recognized, this single tracing did not permit accurate measurements of the various intervals, such as the PR, QT, QRS, etc. The effects of various phases of the surgical procedure on the electrical activity of the heart were observed, and the diagnostic and prognostic value of the observed electrocardiographic changes was evaluated.

No variation in cardiac signal was correlated with the administration of ether or cyclopropane. Irregularities, such as ventricular ectopic beats, flattening of the $\mathrm{T}$ and $\mathrm{P}$ waves, and occasional atrioventricular dissociation due to hypoventilation were observed with both agents Deepening of the anaesthetic level, as routinely done shortly before actual bypass, often improved the electrocardiographic tracing.

Frequent premature ventricular contractions were noted in 21 of the 25 patients when the chest was opened. This was particularly observed with the introduction of large retractors and rib manipulation in the left side of the thorax. In 2 patients, transient ventricular fibrillation was recorded. In 7 patients, P-wave flattening and disappearance, with PR-interval changes and atrioventricular dissociation occurred intermittently. Pericardial incision occasionally produced ectopic beats and $\mathrm{P}$-wave variation. In all 25 patients, palpatation of the heart and insertion of a needle for intraventricular blood sampling produced marked changes which included long runs of ventricular ectopic beats, runs of ventricular tachycardia, and even short episodes of ventricular fibrillation. Atrial manipulation with insertion of the venous cannulae produced premature ventricular contractions and various degrees of heart block in 10 of the patients. In the 2 patients with transposition of the great vessels, coronary artery dissection produced grossly abnormal irreversible electrocardiographic tracings with 
severe arrhythmias, dropped beats, and wide QRS complexes. In all other patients, the changes noted were transient, required no therapy, and were unrelated to prognosis. An increased tendency to the occurrence of cardiac abnormalities was noted in those patients with more severe pulmonary hypertension, in infants, and in younger chuldren.

With the onset of cardiopulmonary bypass, ventricular ectopic beats were occasionally seen, but most of the patients developed generally improved electrocardiographic tracung and a slow rate. In most patients this improvement continued during extracorporeal circulation except when the cardiac beat was arrested with potassium, which produced progressive broadening and widening of the QRS complexes and the T waves, followed in seconds to 20 minutes by complete cardiac standstill. With the return of the cardiac beat, wide QRS complexes, broad $\mathrm{T}$ waves, and elevated ST segments appeared, with gradual progression to a normal tracing over the next hour.

When perfusion was discontınued, ST-segment elevation was noted in eight patients, possibly indicating some myocardial hypoxia during the cardiopulmonary bypass or in the immediate postperfusion period. In most patients, the electrocardiographic tracing improved during closure of the chest and in the immediate postoperative period Prognosis was extremely poor for those patients in whom the elctrocardiogram had not returned to normal or had not approached the preoperative configuration.

\section{Electroencephalographic Observations}

Multıchannel electroencephalographic recording with identical placement of the needle electrodes on the patient's scalp was secured preoperatively, during the surgical procedure, and for postoperative control tracing

Normal preoperative electroencephalograms were obtained in 19 patients. Four children had abnormal tracings with no signs or symptoms of neurological disease One child had cerebral palsy and her preoperative electroencephalogram showed focal changes on the right In one boy with a neonatal head injury, paroxysmal electrical activity was observed preoperatively

Classical electroencephalographic patterns, as described by Gibbs and Gibbs (6), Faulconer $(5)$, and others $(1,4)$ for various planes of anaesthesia, were observed and momentarily confirmed by clinical signs When ether was employed, anaesthesia was maintained in the plane of analgesia in all cases. When cyclopropane was used as the main anaesthetic agent, the depth of anaesthesia was kept at level 2 or 3 of the generally accepted classification (11).

We have not observed the effect of other variables, such as carbon dioxide retention, composition of gases used for aeration of the donor blood during perfusion, or position of the arterial inflow on the configuration of the electroencephalographic pattern $(8-10,12)$. However, isoelectric patterns of varying duration were recorded in four patients durng parlial iriadvertent occlusion of the superior vena cava by the surgeon. There wers no subsequent changes in the postoperative electroencephalographic tracings of these patients and no clunical signs or symptoms of a neurological complication were detected in the recovery period $(3)$. 
electroencephalogram. In the 25 patients observed by us and discussed in this presentation, all changes in configuration of patterns noted durnng any phase of the operation occurred in all leads simultaneously.

We have not observed any deterioration of the electrical cortical activity during manipulation of the heart, or during long periods of cardiac arrhythmias, with the exception of prolonged irreversible ventricular fibrillation (2).

\section{Summary and Conclusions}

The most frequently occurring irregularities of the cardiac rhythm during 25 operations on the opened heart were sinus tachycardia, ventricular premature contractions, atrioventricular block, and ventricular tachycardia and fibrillation. Other changes noted in the configuration of the electrocardiogram included flattening and/or disappearance of $\mathrm{P}$ waves and flattening of $\mathrm{T}$ waves In the majority of the patients, these changes were transient in character, they did not require any drug therapy, and they usually disappeared with temporary interruption or with termination of the surgical procedure.

It was considered a good sign if the configuration of the electrocardiogram, after cessation of the cardiopulmonary bypass, was identical or similar to that observed before perfusion.

Persistence of the electroencephalographic pattern of a light plane of anaesthesia before, during, and afer perfusion was usually consistent with a good prognosis Reduction, both in potentials and frequency durnng extracorporeal circulation or after it, usually carried a poor prognosis

In all instances, changes in electroencephalographic patterns were noted in all leads, thus indicating equal perfusion of all parts of the brain during extracorporeal circulation We have no explanation as to why electroencephalographic evidence of brain damage developed in four patients postoperatively.

\section{ACKNOWLEDGMENTS}

We gratefully acknowledge the technical assistance of Miss Dorothy M. Wagner and Miss Doris C. Thomas in securing the work used in this study.

\section{RÉSUMÉ}

Nous avons obtenu des tracés électroencéphalographiques et électrocardıgraphiques chez 25 malades subissant des corrections chirurgicales de diverses maladies cardiaques congénitales Ces opérations ont été fartes à l'arde d'une dérivation cardıopulmonarre en employant l'écran oxygénateur de Gibbon.

Les irrégularités du rhythme cardiaque les plus fréquemment observées ont été une tachycardie sinusale, des contractions ventriculaires prématurées, un blocage atrioventriculaire, une tachycardie ventriculaire et une fibrillation Parmi les autres changements observés sur le tracé, nous avons observé un abaissement et une disparition des ondes $\mathrm{P}$ et un abassement des ondes T. Dans la plupart des cas, ces changements ont été passagers, ils n'ont requis aucune médication et 
ils disparaissaent après un arrêt temporaire ou avec la fin de l'opération. Nous avons observé que ces irrégularités survenaient en certains temps opératoires ( la mise en place de gros écarteurs et la manipulation des côtes, l'incisıon du pérıcarde, la manipulation du coeur et l'introduction d'une algulle pour échantillonnage de sang et la canulation de veines). Nous avons considéré que le pronostic était bon lorsque le tracé électrocardiographique, après la cessation de la dérivation' cardiopulmonarre, étart semblable ou se rapprochait de celui que nous avions pris avant l'opération

Des tracés électroencéphalographıques obtenus avec des électrodes argulles placées aux mêmes endroits sur le scalpe des malades avant, pendant et après les opératıons ont été comparés Nous voulions nous assurer si l'apport de sang oxygéné etait adéquat dans certaines zones cérébrales durant la dérivation cardiopulmonaire et, sı oui, vérifier si cela pouvait apporter des changements localisés sur le tracé électroencéphalographique. Sur es 25 malades observés et étudiés dans ce traval, tous les changements sur les tracés observés à tous les temps opératoires sont apparus dans toutes les dérivations sirnultanément La persistance d'un type de tracé électroencéphalographique comparable à ce ui d'un plan léger d'anesthésie avant, pendant et après la perfusion était habituellement de bon augure. Une dımınution des potentiels et de la fréquence durant la circulation extracorporelle ou après était consıdérée comme un mauvass pronostic.

\section{REFERENCES}

1. Artusio, J. F Ether Analgesıa during Major Surgery J.A M A 15733 (1955)

2. Bellvitle, J W, Artusio, J F, \& GlenN, F The Electroencephalogram during Cardiac Mampulation Surgery 38259 (1955).

3. Brechner, V. L, Kavan, E M, \& Dillon, J 3 The Electroencephalographic Effect of Compression of the Superior Vena Cava durıg Thoracotomy. J. Thoracic Surg 37. 352 (1959).

4. Courtin, R. F, Bickford, R G, \& Faulconer, A., Jrit The Classification and Significance of Electroencephalographic Patterns Produced by Nitrous Oxide-Ether Anesthesia during Surgical Operations Proc Mayo Clinic 25197 (1950)

5 Faulconer, A, Jr Correlation of Concentration of Ether in Arterial Blood with Electroencephalographic Patterns Occurring during Ether--Oxygen and during Nitrous Oxide, Oxygen and Ether Anesthesia of Human Surgical Patients Anesthesiology $13 \quad 361$ (1952).

6. Gibss, F. A, Gibes, E L , \& Lennox, W. G. Effect on Electroencephalogram of Certain Drugs Which Influence Nervous Activity Arch Int Med. 60 154 (1937)

7. Maloney, J V., Jr, Longmire, W P, Jr, Schmutze.r, K J , Marable, S A, Raschike, E., Watanabe, Y, Lobpreis ${ }_{\alpha}$ E L, \& Arzouman, J E. An Experimental and Clinical Comparison of the Bubble Dispersion and Stationary Screen Pump Oxygenators Surg., Gynec \& Obst 107577 (1958).

8. Mendelsokn, D , Jr., MacKrel., T. N, Maclachlan, M. A., Cross, F S, \& Kay, E. B Expenences Using the Pump Oxygenator for Open Cardıac Surgery/ in Man Anesthesılogy 18223 (1957).

9. Patrick, R. T., Kirkin, J. W., \& Theye, R. A. The Effects of Extracorooreal Circulation on the Brain, in Extracorporeal Circulation, pp 272-277. Springfield, I.1 C. C Thomas

10. Pathick, R T, Theye, R. A., \& Moffitt, E. A. Studies in Extracorporeal Circulation. V, Anesthesia and Supportive Care during Intracardac Surgery with the Gibbon Type Pump-oxygenator. Anesthesiology 18: 673 (1957). 
11. Possati, S, Faulconer, A. Jr, Brckford, R. G, \& Hunter, R. C. Electroencephalographic Pattesns during Anesthesia with Cycloprosane: Correlation with Concentrations of Cyclopropane in Arterial Blood Anesth \& Ana.g. 32 ] 30 (1953).

12. Theye, R. A., PAtruck, R T, \& Kirkin, J W The Electroencephalogram in Patients Undergoing Open Intracardiac Operations with the Ald of Extracorporeal Circulation. J. Thoracic Surg. 34: 709 (1957).

13. Walter, R. D, Kavan, E M; Brechner, V. L , \& Maloney, J. V., Jr. Electroencephalographic Changes during Cardiac Surgery with Cardiopulmonary Bypass. Electroencephalog. \& Cln. Neurophysiol 10180 (1958). 